\title{
Hyperosmolar non-ketotic diabetes
}

\author{
Michael B. MacaulaY* \\ M.A., D.M., M.R.C.P. \\ Senior Medical Registrar, Medical Division, Sefton General Hospital, Liverpool L15 2HE
}

\section{Summary}

Hyperosmolar non-ketotic crises occur chiefly in mild, maturity-onset diabetics, yet present a medical emergency carrying a high mortality. This may in part be due to a lack of awareness of the clinical presentation, and of the principles of treatment. Five cases are described, in all of which excessive consumption of Lucozade, a proprietary 'glucose' drink, played an important part in the development of their hyperosmolar state.

\section{Introduction}

In 1886 Dreschfeld distinguished a rare form of diabetic coma without ketosis. Occasional reports of similar cases have appeared since (Rosenbloom, 1915; Joslin, 1917; Warburg, 1925), but modern interest in non-ketotic diabetic coma has been aroused following the case reports by de Graeff \& Lips (1957) and Sament \& Schwartz (1957). Since then the concept has developed of hyperglycaemic coma due to hyperosmolarity of the plasma and extracellular fluid.

Characteristically, the patients are middle-aged or elderly and have not previously been recognized as diabetics. They are severely dehydrated, aketotic and have very high blood sugar levels, but if they recover the diabetes can usually be controlled without insulin. The high osmolarity of the plasma is produced by raised levels of sugar, sodium and urea in varying proportions. Usually referred to as hyperosmolar non-ketotic diabetic coma, it seems preferable to omit the final word, since coma only occurs at an advanced stage. The condition appears to be occurring more commonly (Sølvsteen, Olsen \& Hansen, 1968; Martin, 1968) and the mortality is about 50\% (Di Benedetto, Crocco \& Soscia, 1965; Jackson \& Forman, 1966; Halmos, Nelson \& Lowry, 1966).

Five further cases, four seen within a period of 9 months, are reported here to draw attention to an important aetiological factor, to stress the difficuty and importance of early diagnosis and to propose a rational basis for treatment.

\section{Case reports}

Detailed biochemical findings in the five patients

* Present address: Walton Hospital, Rice Lane, Liverpool L9 1AE. are recorded in Table 1 . In every case the history was obtained from the relatives or only in retrospect from the patient, since no patient was fit to give a history on admission.

\section{Case 1}

Mrs M.S., a 67-year-old housewife, had been losing weight for about 6 months; she had felt generally unwell for about 4 weeks with a poor appetite and undue thirst, which she quenched by drinking $1-2$ bottles of Lucozade daily. She had been confused for 5 days before admission, and practically stuporous for 2 days.

In addition to being stuporous, she was severely dehydrated, but there was no ketosis or acidotic breathing, and although her urine contained $2 \%$ sugar, there was no acetone. She was treated as a diabetic coma with insulin and rapid intravenous infusion of 2.51 of isotonic $(0.9 \%)$ sodium chloride followed by alternate $500 \mathrm{ml}$ bottles of $5 \%$ dextrose and isotonic saline together with potassium supplements. The following day she was less dehydrated but there was no change in her stupor, the hypernatraemia was worse and hyperglycaemia still considerable (Table 1). Saline was discontinued and subsequent treatment consisted of infusion of $5 \%$ dextrose with potassium supplement and insulin, but nevertheless her plasma sodium took 4 days to fall to normal and although she became fully orientated and rational at about the same time, she remained drowsy for about 3 weeks. She has been a bad attender at the diabetic clinic, but on the two occasions she has been seen, her diabetes has been well controlled with chlorpropamide $250 \mathrm{mg}$ daily.

\section{Case 2}

Mrs E.R., an obese 59-year-old housewife, had been a known diabetic for 4 years. Treatment had been attempted with a low carbohydrate diet, but she was casual in her attitude and had been taken off the clinic books after missing five consecutive appointments. Ten days before admission she developed 'flu' and from then on had consumed two bottles of Lucozade daily. The day before admission she had vomited several times and her family noticed that she had become confused and sleepy. 
TABLE 1. Details of five patients with hyperosmolar diabetes

\begin{tabular}{|c|c|c|c|c|c|}
\hline & Case 1 & Case 2 & Case 3 & Case 4 & Case 5 \\
\hline Age and Sex & MS (67) F & Er (59) $F$ & $\mathrm{FW}(62) \mathrm{M}$ & $\mathrm{OM}(53) \mathrm{F}$ & LN (69) F \\
\hline Known diabetic & No & Yes & No & No & No \\
\hline $\begin{array}{l}\text { History of Lucozade drinking } \\
\text { Duration } \\
\text { Amount }\end{array}$ & $\begin{array}{l}4 \text { weeks } \\
1-2 \text { bottles/ } \\
\text { day }\end{array}$ & $\begin{array}{l}10 \text { days } \\
2 \text { bottles/ } \\
\text { day }\end{array}$ & $\begin{array}{l}4 \text { days } \\
10 \text { bottles/ } \\
4 \text { days }\end{array}$ & $\begin{array}{l}\text { Few weeks } \\
1-2 \text { bottles/ } \\
\text { day }\end{array}$ & $\begin{array}{l}6 \text { weeks } \\
2 \text { bottles/ } \\
\text { day }\end{array}$ \\
\hline Admission diagnosis & $\begin{array}{l}\text { Diabetic } \\
\text { coma }\end{array}$ & $\begin{array}{l}\text { Diabetic } \\
\text { precoma; } \\
\text { broncho- } \\
\text { pneumonia }\end{array}$ & Stroke & $\begin{array}{l}\text { Broncho- } \\
\text { pneumonia }\end{array}$ & $\begin{array}{l}\text { Arteriosclerotic confu- } \\
\text { sion. Diabetes dis- } \\
\text { covered on urine test- } \\
\text { ing, but thought to be } \\
\text { mild }\end{array}$ \\
\hline \multicolumn{6}{|l|}{ Initial blood biochemistry } \\
\hline $\begin{array}{l}\text { Blood sugar }(\mathrm{mg} / 100 \mathrm{ml}) \\
\text { Plasma urea }(\mathrm{mg} / 100 \mathrm{ml}) \\
\text { Plasma sodium }(\mathrm{mEq} / 1) \\
\text { Plasma potassium }(\mathrm{mEq} / 1) \\
\text { Plasma chloride }(\mathrm{mEq} / 1) \\
\text { Plasma bicarbonate }(\mathrm{mEq} / 1) \\
\text { Calculated osmolarity* }\end{array}$ & $\begin{array}{c}740 \\
353 \\
153 \\
5 \cdot 2 \\
102 \\
21\end{array}$ & $\begin{array}{l}600 \\
136 \\
155 \\
4 \cdot 5 \\
116 \\
-\end{array}$ & $\begin{array}{c}1070 \\
225 \\
158 \\
3 \cdot 9 \\
115 \\
-\end{array}$ & $\begin{array}{c}647 \\
75 \\
158 \\
3 \cdot 6 \\
125 \\
-\end{array}$ & $\begin{array}{c}754 \\
43 \\
166 \\
3 \cdot 9 \\
125 \\
22\end{array}$ \\
\hline \multicolumn{6}{|l|}{$\begin{array}{l}\text { Repeat blood biochemistry } \\
(2-24 \text { hr after starting treat- } \\
\text { ment) }\end{array}$} \\
\hline $\begin{array}{l}\text { Blood sugar }(\mathrm{mg} / 100 \mathrm{ml}) \\
\text { Plasma urea }(\mathrm{mg} / 100 \mathrm{ml}) \\
\text { Plasma sodium }(\mathrm{mEq} / 1) \\
\text { Plasma potassium }(\mathrm{mEq} / 1) \\
\text { Plasma chloride }(\mathrm{mEq} / 1) \\
\text { Plasma bicarbonate }(\mathrm{mEq} / 1) \\
\text { Calculated osmolarity* }\end{array}$ & $\begin{array}{l}535 \\
265 \\
167 \\
4 \cdot 9 \\
116 \\
29\end{array}$ & $\begin{array}{c}168 \\
90 \\
164 \\
3 \cdot 9 \\
124 \\
27 \cdot 5\end{array}$ & $\begin{array}{l}960 \\
243 \\
178 \\
2 \cdot 7 \\
106 \\
26\end{array}$ & $\begin{array}{c}304 \\
97 \\
154 \\
3 \cdot 3 \\
128 \\
6 \cdot 1\end{array}$ & $\begin{array}{r}270 \\
59 \\
157 \\
3 \cdot 9 \\
123 \\
23\end{array}$ \\
\hline (mosmol/1) & 408 & 352 & 449 & 352 & 339 \\
\hline $\begin{array}{l}\text { Time taken for plasma sodium } \\
\text { to fall to normal levels }\end{array}$ & 4 days & 6 days & - & 3 days & 3 days \\
\hline Eventual diabetic control & $\begin{array}{l}250 \mathrm{mg} \\
\text { chlorpro- } \\
\text { pamide } \\
\text { daily }\end{array}$ & $\begin{array}{l}250 \mathrm{mg} \\
\text { chlorpro- } \\
\text { pamide } \\
\text { daily }\end{array}$ & $\begin{array}{l}\text { Patient died } \\
\text { within } 3 \mathrm{hr} \\
\text { of diagnosis } \\
\text { of diabetes }\end{array}$ & $\begin{array}{l}250 \mathrm{mg} \\
\text { chlorpro- } \\
\text { pamide } \\
\text { daily }\end{array}$ & $\begin{array}{l}375 \mathrm{mg} \text { chlorpropamide } \\
\text { daily }\end{array}$ \\
\hline
\end{tabular}

* Serum osmolarity (SO) has been calculated from the formula:

$\mathrm{SO}(\mathrm{mOsm} / \mathrm{kg})=2 \times \operatorname{sodium}(\mathrm{mEq} / 1)+\frac{\text { urea }(\mathrm{mg} / 100 \mathrm{ml})}{6}+\frac{\operatorname{sugar}(\mathrm{mg} / 100 \mathrm{ml})}{18}$

(Mahon et al., 1968)

On examination she was drowsy, irrational, abusive and severely dehydrated. There was tenderness without guarding in the epigastrium, and coarse crepitations were heard at both lung bases. There was no clinical evidence of ketosis or acidosis, and the urine contained $2 \%$ sugar but no acetone. A chest $\mathrm{X}$-ray showed bilateral bronchopneumonia.

She was treated as a diabetic pre-coma, with insulin, ampicillin and rapid intravenous infusion of 1.51 of isotonic saline followed by alternate $500 \mathrm{ml}$ bottles of isotonic saline and $5 \%$ dextrose with potassium supplements. Twelve hours after admission she still appeared dehydrated, without any change in her mental state, and although the hyperglycaemia had lessened, the hypernatraemia was worse (Table 1). From this time on, she was given alternate bottles of $0.45 \%$ saline and $5 \%$ dextrose, and was encouraged to drink freely. She steadily improved, and appeared mentally normal by the third day, but the serum sodium did을 not fall below $150 \mathrm{mEq} / \mathrm{l}$ until the sixth day. Sha has since been well controlled with chlorpropamide $250 \mathrm{mg}$ daily and is regularly attending the diabetic clinic.

\section{Case 3}

Mr F.W., a 62-year-old retired joiner, had com $\frac{0}{2}$ plained of weakness and parasthesiae in his right? arm for 6 months, and had been treated for cervicalo spondylosis. He had felt generally weak and tirec $\overrightarrow{\mathrm{P}}$ for several months, but had been confused for onlys a week. His wife later said that he had been vers 
thirsty with a 'sweet tooth' for several weeks and that he had drunk ten bottles of Lucozade in the 4 days prior to admission, four of them on the final day. No history of the orthopaedic treatment or the thirst was obtained on admission.

On examination he was confused, rambling and incontinent. Weakness was noted in his right arm and both plantar responses were extensor. He was thought to have had a stroke, and because of his incontinence, routine urine testing was not done. Over the next $24 \mathrm{hr}$ he became deeply unconscious and hypotensive, and the omission of routine urine testing was noticed. He had become severely dehydrated, there was a faint smell of acetone on his breath, and his blood sugar proved to be 1070 $\mathrm{mg} / 100 \mathrm{ml}$.

He was treated as a diabetic coma with intravenous insulin and isotonic saline. Ninety min after the first diagnosis of diabetes he had received 1.51 of isotonic saline and $100 \mathrm{ml} 8.4 \%$ sodium bicarbonate. At this time his blood pressure (BP) was unrecordable and when the results of the electrolyte estimations were learnt, the intravenous fluid was changed to half-strength plasma, but he died within an hour. Necropsy demonstrated marked cerebral and coronary atheroma with myocardial fibrosis and pulmonary oedema, so this patient could have died without the diagnosis of diabetes ever having been made.

\section{Case 4}

Mrs O.M., a 54-year-old housewife, had felt generally unwell, and had been very thirsty for several weeks. During this time she had been drinking one or two bottles of Lucozade daily. She had been diagnosed as having 'flu' and bronchitis 10 days before admission, and had been increasingly confused for 7 days. The day before admission she had vomited several times and had gradually become stuporous. She was referred to hospital at the height of an influenza epidemic as a severe case of influenzal bronchopneumonia.

On examination she was dyspnoeic, stuporous and severely dehydrated, with a faint smell of acetone on her breath. There were coarse rhonchi throughout the lung fields, and chest X-ray showed bronchopneumonic shadowing in her right upper lobe. Routine examination of the urine showed $2 \%$ sugar with a moderate amount of acetone on Acetest. The diagnosis of hyperosmolar diabetes was suspected and rapid infusion with $0.45 \%$ saline together with insulin was started, while awaiting the initial blood sugar and plasma electrolyte levels. Three litres of $0.45 \%$ saline were infused in the first 3 $\mathrm{hr}$, then $5 \%$ dextrose with additional potassium chloride was given more slowly. She remained stuporous for $24 \mathrm{hr}$ and did not become completely rational for 3 days. Her pyrexia persisted, and Mycobacterium tuberculosis was cultured from three specimens of sputum, but she has responded well to treatment with streptomycin, isoniazid and PAS, and her diabetes is well controlled with $\mathbf{2 5 0}$ mg chlorpropamide daily.

\section{Case 5}

Mother L.N., a 69-year-old nun, had been unwell and tired for 2 or 3 months. She had noticed thirst and polyuria for about 2 months and had been drinking two bottles of Lucozade daily for at least 6 weeks. She had started to feel very ill and shivery 10 days before admission, and had been increasingly confused for a week.

On examination she was drowsy as well as confused and slightly pyrexial $\left(99^{\circ} \mathrm{F}\right)$, but she did not appear dehydrated, acidotic or ketotic, and the urine contained $2 \%$ sugar but no acetone. A diagnosis of cerebral arteriosclerosis and diabetes was made, and it was not at first appreciated that the diabetes was responsible for her mental state. Once the initial biochemical results (Table 1) were known she was given insulin and a slow intravenous infusion of $0.45 \%$ saline. In $6 \mathrm{hr}$ the blood sugar had been lowered to $270 \mathrm{mg} / 100 \mathrm{ml}$ and from then on only $5 \%$ dextrose with additional potassium chloride was infused. In spite of this her serum sodium did not return to normal for 3 days, and she was not rational or mentally alert until the third day. The pyrexia persisted for 3 weeks and then settled without any cause being found.

Her diabetes is at present well controlled with $375 \mathrm{mg}$ chlorpropamide daily.

\section{Comment \\ Aetiology}

It is probable that the high consumption of Lucozade (Table 1) by each of the five patients played a major part in the development of their hyperosmolar condition. Lucozade contains $23.5 \%$ liquid glucose BPC(1963). Liquid glucose, in spite of its name, is a hydrolysate of starch containing mainly polysaccharides with $10-20 \%$ dextrose only. As a result Lucozade contains a high proportion of readily assimilable carbohydrate (about $140 \mathrm{~g} /$ bottle) without being too cloyingly sweet to drink in large quantities. It is widely advertised for the restoration of energy to those in ill-health, and it is not surprising that from time to time a mild maturity-onset diabetic, not yet aware of the nature of his disease, feeling ill and thirsty, should consume it in large quantities. The hyperglycaemia thus induced can be expected to produce osmotic diuresis and hypertonic dehydration, thus leading to increasing malaise and greater thirst. A patient 
already diagnosed as diabetic will normally avoid glucose drinks unless he is neglectful and casual of his condition.

It is possible but unlikely that this high incidence of excessive Lucozade drinking is a coincidence, it being more likely that the increase in frequency of hyperosmolar diabetes, if real, has been produced by the ready availability of palatable invalid drinks with a high carbohydrate content out of proportion to their sweetness.

Other authors have speculated that a high carbohydrate intake might be an important factor in producing hyperosmolar diabetes (Lucas et al., 1963; Di Benedetto et al., 1965; Sølvsteen et al., 1968). Di Benedetto et al. report that one of their patients had an intense craving for sweets and carbonated drinks, and McConnel, Chaturvedi \& Logan (1969) report a patient whose hyperosmolar diabetic state was precipitated by excessive intake of a 'carbonated, concentrated carbohydrate drink' very similar to Lucozade in content.

\section{Clinical features}

Coma is an unfortunate term to apply to hyperosmolar diabetes since deep unconsciousness has not been a presenting feature in many of the previously reported cases, or in three of these five. The commonest picture has been that of increasing drowsiness and confusion (Di Benedetto et al., 1965; Sølvsteen et al., 1968; Martin, 1968). In this series some degree of confusion tended to persist for several days in spite of adequate rehydration, and in the four patients who survived, return to a normal mental state coincided closely with the fall of serum sodium to normal levels.

Dehydration is usual, although it was not present in Case 5 of this series. Ketosis is unusual, but may be present in slight degree, and when acidosis has occurred it has been attributed to the development of lactic acidosis from tissue breakdown (Danowski \& Nabarro, 1965). Case 4 was slightly ketotic with a plasma bicarbonate of $6 \mathrm{mEq} / 1$, yet illustrated all the other features of hyperosmolarity. This usual lack of ketoacidosis may prevent consideration of a clinical diagnosis of diabetes in a confused, dehydrated patient, the history of thirst may be missed if the relatives are not specifically questioned and incontinence may prevent routine urine testing, as happened in Case 3.

All the patients in this series were maturity-onset diabetics and the only one who had been previously diagnosed as such had neglected her condition. None subsequently required insulin, this being consistent with the experience of others, although insulin-dependent diabetics may also develop hyperosmolarity without ketosis (Mahon, Holland \& Urowitz, 1968).

\section{Biochemical features}

All patients have greatly raised blood sugar levels, $\frac{2}{d}$ The range in this series was $600-1070 \mathrm{mg} / 100 \mathrm{ml} \stackrel{\mathrm{a}}{\mathrm{a}}$ and in the cases reviewed by $\mathrm{Di}$ Benedetto et al. $\stackrel{\hookrightarrow}{\longrightarrow}$ (1965) levels varied from 460 to $2200 \mathrm{mg} / 100 \mathrm{ml}$. $\stackrel{\overrightarrow{\vec{S}}}{\vec{q}}$ The osmotic diuresis produced by glycosuria is responsible for the striking dehydration seen in so many patients.

Hypernatraemia was present in all five patients in this series, and took from 3 to 6 days to return to normal. Of the patients reviewed by Di Benedetto et al. the serum sodium level was between 150 and $\overrightarrow{0}$ $174 \mathrm{mEq} / 1$ in $64 \%$, and between 140 and $150 \vec{\overrightarrow{ }}$ $\mathrm{mEq} / 1$ in a further $12 \%$. Brodsky, Rapoport \& ${ }_{\sigma}^{\omega}$ West (1950) have shown that the osmotic diuresis produced by glucose in dehydrated diabetics is 3 accompanied by a marked fall in urinary sodium concentration, and hypertonic dehydration is there- $v$ fore produced by continued loss of water in excess of $\frac{\vec{\sigma}}{\sigma}$ salt. Aldosterone may be a mediating mechanism here, for the hypovolaemia could be expected to $\stackrel{\bullet}{-}$ lead to aldosterone secretion and hence further $ᄋ$ salt retention.

By definition, hyperosmolarity of the extra- $\frac{7}{2}$ cellular fluid is a constant feature of this disorder. The initial plasma osmolarity calculated in this $\vec{\varphi}$ series varied from 371 to $413 \mathrm{mosmol} / 1$ (normgi 285-295 mosmol/1. To a large extent this hyper osmolarity is caused by the hyperglycaemia, but the variably increased levels of sodium and urea also contribute, and a consideration of the formula quoted in Table 1 shows that a $10 \mathrm{mEq} / 1$ rise in $\frac{0}{\varnothing}$ serum sodium has the same osmotic effect as a 360 을 $\mathrm{mg} / 100 \mathrm{ml}$ rise in blood sugar. This high extra- $\overline{-}$ cellular osmolarity leads to an intracellular dehydra- 3 tion which is probably responsible for the changes in conscious level and mental state (Macarrio, Messis \& Vastola, 1965; Di Benedetto et al., 1965).

\section{Treatment}

The aim of treatment should be to reduce the osmolarity of the extracellular fluid while re-을 hydrating the patient. In previous reports insulin requirements have varied from enormous (Halmos et al., 1966) to none (Hayes \& Woods, 1968). Since? the high blood sugar is the one factor contributing to hyperosmolarity that can be altered quickly ito seems reasonable to give insulin in adequate doses son as to quickly reduce it to as near normal as possible, repeating estimations of its level at frequent ${ }^{\omega}$ intervals. This is in contrast with the situation in ketoacidosis where it is preferable to maintain the blood sugar at higher than normal levels untie ketosis is abolished. It is suggested that the initiaf dose of insulin should be 100 units intravenously if the blood sugar is above $600 \mathrm{mg} / 100 \mathrm{ml}$ and $200 \overrightarrow{\mathrm{D}}$ units intravenously if above $800 \mathrm{mg} / 100 \mathrm{ml}$. 
Large quantities of intravenous fluids are required to correct severe dehydration. Lucas et al. (1963) gave 171 to one patient in $12 \mathrm{hr}$, and it should be remembered that the rapid movement of extracellular sugar to intracellular sites under the influence of insulin will take water out of the extracellular compartment and increase any hypovolaemic shock unless fluid is replaced rapidly. This same movement of water may be responsible for the rise in plasma sodium which occurs frequently in the early stages of treatment. Modern techniques of central venous pressure monitoring should make the rate of fluid replacement easier to control.

There has been continued debate as to the correct fluids to use. Sament (1966), Haapenen (1966) and Martin (1968) have all favoured isotonic saline. Sament reasoned that there was a total body deficiency of sodium masked by the pronounced dehydration, and Rosen \& Glick (1966) have pointed out that isotonic fluids are hypotonic in relation to the hyperosmolar body fluids. Halmos et al. (1966) and Nelson (1966) have favoured the use of isotonic $5 \%$ dextrose on the grounds that the dextrose is quickly assimilated and the water is then available for rehydration. McConnel et al. (1969) suggest that it is reasonable to infuse distilled water, while others $(\mathrm{Di}$ Benedetto et al., 1965; Rosen \& Glick, 1966; Sølvsteen et al., 1968) have used hypotonic saline solutions.

Isotonic saline was used initially in Cases 1-3 and in each the plasma sodium level rose in the first few hours of treatment (Table 1), the sharp rise in Case 3 probably contributing to his death. Hypotonic saline $(0.45 \%)$ was used in Cases 4 and 5 with a resultant slight fall in plasma sodium level. Since isotonic dextrose increases the plasma hyperosmolarity and distilled water carries the risk of intravascular haemolysis the following is suggested as a reasonable regime for fluid replacement: Hypotonic $(0.45 \%)$ saline should be infused until the initial plasma sodium level is known; if raised, hypotonic saline should be continued until the blood sugar level has returned to near normal levels. At this point the infusion should be changed to isotonic dextrose, continuing to keep the blood sugar level near normal with insulin. As soon as the patient can take fluids by mouth, water should be given liberally. There is no value in attempting to replace sodium deficit in the body in the early stages of emergency treatment if the serum sodium level is raised, and isotonic saline should only be used if the sodium level is low.

The plasma potassium level falls as dextrose is utilized and careful monitoring of its level is necessary in order to ensure the addition of adequate supplements.

\section{Conclusions}

1. Hyperosmolar diabetes carries a high mortality and may prove to be an increasingly common medical emergency.

2. Excessive consumption of Lucozade can play an important part in the development of hyperosmolarity in otherwise mild diabetics. It was incriminated in all five cases described here.

3. Treatment requires the generous use of insulin combined with rapid intravenous rehydration. Hypotonic $(0.45 \%)$ saline should be infused initially, followed by isotonic dextrose as soon as the blood sugar has been lowered to normal levels, and potassium supplements are necessary. These procedures can most safely be carried out with frequent monitoring of central venous pressure, plasma electrolytes and blood sugar.

4. The characteristic clinical picture is one of thirst, increasing confusion and severe dehydration in a middle-aged or elderly patient not known to be a diabetic. Greater awareness of this presentation, together with greater understanding of the principles of treatment should lead to a diminution in mortality.

\section{Acknowledgments}

I am grateful to Dr C. M. Miller F.R.C.P. for encouraging me to write this paper, and to Dr Miller and Dr H. Fuld F.R.C.P.(Ed.) for allowing me to publish details of patients admitted under their care. Dr John Wilson M.R.C.P. was the first to suggest the possibility of an association between excessive Lucozade consumption and hyperosmolarity in Case 1.

\section{Addendum}

Since submitting this manuscript a further case of hyperosmolar diabetic crisis associated with excessive Lucozade consumption has been seen.

Mrs A.W., a 70-year-old woman, not previously known to be a diabetic, had been thirsty for 4 weeks. She had been drinking 2-3 bottles of Lucozade daily for at least 2 weeks and had drunk four bottles in the $24 \mathrm{hr}$ prior to admission. Three days before hospital admission she vomited and thereafter became increasingly drowsy and confused.

On examination she was drowsy, confused and severely dehydrated, with a blood pressure of $140 / 90$. Urine was loaded with sugar and showed a trace only of ketones. There was no acidotic breathing or smell of acetone on her breath. Blood biochemistry was as follows: blood sugar $1100 \mathrm{mg} / 100 \mathrm{ml}$. Plasma sodium $160 \mathrm{mEq} / \mathrm{l}$, potassium $2.6 \mathrm{mEq} / 1$, chloride $101 \mathrm{mEq} / 1$, urea $109 \mathrm{mg} / 100 \mathrm{ml}$. Calculated osmolarity 399 mosmol/l. Over a period of a few days she made an uneventful recovery with treatment with insulin and intravenous fluids, and her diabetes appeares to be well controlled with oral hypoglycaemic agents.

I am grateful to Dr I. Ansell for permission to report this case.

\section{References}

Brodsky, W.A., Rapoport, S. \& West. C.D. (1950) Mechanism of glycosuria diuresis in diabetic man. Journal of Clinical Investigation, 29, 1021.

DanowsKy, T.S. \& NABARRO, J.D.N. (1965) Hyperosmolar and other types of non-ketotic coma in diabetes. Diabetes 14, 162. 
Di Benedetto, R.J., Crocco, J.A. \& Soscia, J. L. (1965) Hyperglycemic nonketotic coma. Archives of Internal Medicine (Chicago), 116, 74.

DRESChFELD, J. (1886) Diabetic coma. British Medical Journal, 11, 358.

DE GRAEFF, J. \& LIPS, J.B. (1957) Hypernatraemia in diabetes mellitus. Acta medica scandinavica, 157, 71 .

HAAPANEN, E. (1966) Hyperosmolar coma in diabetes. Lancet, i, 1154

Halmos, P.B., Nelson, J.K. \& Lowry, R.C. (1966) Hyperosmolar non-ketoacidotic coma in diabetes. Lancet, i, 675.

HAYES, T.M. \& Woods, C.J. (1968) Hyperosmolar nonketotic coma. Lancet, i, 209.

JACKSON, W.P.U. \& FoRMAN, R. (1966) Hyperosmolar nonketotic diabetic coma. Diabetes, 15, 714.

JosıIN, E.P. (1917) The Treatment of Diabetes Mellitus, 2nd edn, p 88. Lea \& Febiger, Philadelphia and New York.

Lucas, C.P., Grant, N., Daily, W.J. \& Reaven, G.M. (1963) Diabetic coma without ketoacidosis. Lancet, i, 75.

Macarrio, M., Messis, C.P. \& Vastola, E.F. (1965) Focal seizures as a manifestation of hyperglycemia without ketoacidosis. Neurology, Minneap. 15, 195.

McConnell, J.B., Chaturvedi, N.C. \& Logan, J.S. (1969) Hyperglycaemic nonketotic coma in diabetes occasioned by a concentrated carbohydrate drink. Ulster Medical Journal, 38, 150.

Mahon, W.A., Holland, J. \& URowitz, M.B. (1968) Hyperosmolar, non-ketotic diabetic coma. Canadian Medical Association Journal, 99, 1090.

MARTIN, A. (1968) Hyperosmolar non-keto-acidotic diabetic $\overrightarrow{\vec{F}}$ coma. Postgraduate Medical Journal, 44, 218.

NelsoN, J.K. (1966) Hyperosmolar coma in diabetes. Lancet, i, 1376.

RoSEN, H. \& Glick, S.M (1966) Hyperosmolar coma in diabetes. Lancet, i, 1101.

Rosenbloom, J. (1915) A form of diabetic coma not due to $\varrho$ acetone bodies. New York Medical Journal, 102, 294.

SAMENT, S. (1966) Hyperosmolar coma in diabetes. Lancet, ii, 549.

SAMENT, S. \& Schwartz, M.B. (1957) Severe diabetic stupor without ketosis. South African Medical Journal, 31, 893.

Sølvsteen, P., Olsen, V.V. \& Hansen, E.L. (1968) Diabetic coma without ketoacidosis. Acta medica scandinavica 184, 83.

WARBURG, E. (1925) Some cases of diabetic coma com-plicated with ureaemia, and some remarks on the previous history of the diabetic coma. Acta medica scandinavica, o 61, 301 . 